\title{
Assessment of Traffic Noise Pollution Impact of Residential/Commercial Development
}

Nayef Al-Mutairi

Civil Engineering Department, College of Engineering and Petroleum, Kuwait University, Kuwait

\begin{abstract}
This paper the findings of an environmental impact study aimed at determining traffic-generated noise pollution impact of new Township Redevelopment Project in Ahmadi, Kuwait. The specific objectives of the study were no measure traffic flow variables; Traffic-generated noise; examine and compare noise pollution compliance with the EPA standards; and recommend mitigation measures. Eight representative roadway locations were systematic - randomly selected for monitoring traffic flow and noise levels. At each monitoring site, the study variables were monitored during six daily peak periods. In addition, data were also collected on atmospheric conditions - temperature, wind velocity and direction and humidity for each monitoring day.
\end{abstract}

Keywords: Environmental impact study; Noise pollution; Mitigation measures

\section{Introduction}

This paper presents the findings of an environmental impact study aimed at determining traffic-generated noise pollution impact of the New Township Redevelopment Project in Ahmadi, Kuwait.

Noise is undesirable/unwanted sound, extended exposure to which has been shown to produce physical and psychological damage. Because of its annoyance and disturbance implications, noise adds to mental stress and thus affects the general well-being of exposed urban population [1-4]. In non-industrial nations, in general, and in the oilrich nations of the Persian Gulf, in particular, rapid growth in income, car ownership and inexpensive fuel have combined to result in a large number of daily trips and thus exacerbate the problem of traffic noise pollution in expanding urban areas of the region [5].

\section{The study area}

The study area is located in Ahmadi, an oil township located some $50 \mathrm{Km}$ to the south of the capital - metropolitan Kuwait. The main aim of the Ahmadi Township Redevelopment is to carry out a total reconstruction of all Kuwait Oil Company (KOC) housing and to provide with all amenities necessary for a modern residential development. The redeveloped township will include 3500 houses and the supporting retail and recreational facilities. The area of the redevelopment project is nearly 2.7 million square meters, with an additional 2.18 million square meters for future expansion.

\section{Materials and Methods}

A reconnaissance survey was undertaken to select representative roadway sites for monitoring traffic flow and noise levels. A total of eight representative roadway locations were selected to monitor flow and noise. These roadway locations were selected to represent roadways of different type (functional classification), serving different commercial industrial and residential land-uses. Traffic flow variables (volume and mix) and noise levels were measured simultaneously at each selected roadway site during the morning and the afternoon peak periods, repeated three times each.

In addition, to traffic flow, noise and air pollution, data was also collected on atmospheric conditions during the measurement periods. These included temperature, wind velocity, and humidity. These data were utilized to examine relationships with traffic noise as well as their potential employment in the noise model.

\section{Result and Discussion}

\section{Traffic flow measurement}

A summary of the traffic flow measurements is presented in Table 1 , which indicate that traffic flow at a given roadway location did not vary significantly over the measurement time period, and it was heavier during the afternoon peak hour at all roadway locations. Also noticeable is the volume of heavy trucks and buses at roadway location 4 and 5 , and to some extent at location 1 . With the consideration of the number of lanes per direction (2), and the percentage of heavy trucks, roadway location 5,4 , and 1 are presently operating at level of service between $\mathrm{C}$ and $\mathrm{D}$. Future increase in traffic volume on these roadways may result in heavy congestions during the daily peak hours.

\section{Traffic noise measurement}

Traffic noise was measured (simultaneously with traffic flow) at the selected roadway locations during the peak hours of the day, repeated 3 times. Measurements were taken at approximately one-meter distance from the pavement edge. For each measurement period, the equivalent noise level $\left(\mathrm{L}_{\mathrm{eq}}\right)$, and the standard deviation of noise levels were computed, as presented in Table 2.

As the noise levels in Table 2 show, the problem of traffic-generated noise pollution is present at nearly all roadway monitoring sites and during both morning and afternoon peak hours of the day. Noise levels are higher in the afternoons due to heavier traffic volumes during these periods. With the exception of roadway location no. 7, traffic noise is way above the maximum permitted outdoor standard level of 75 (dBA). At roadway location no. 5, 4, and 1, the level of noise pollution is in the upper $80 \mathrm{dBAs}$, causing annoyance, fatigue and disturbance. Certainly, the increase in noise levels due to increases in traffic volume

*Corresponding author: Nayef Al-Mutairi, Civil Engineering Department College of Engineering and Petroleum, Kuwait University, P.O. Box 5969, Safat 13060 Kuwait, Tel.: +965-481-1188/ext.5736; Fax: +965-481-7524; E-mail: nayef.almutairi@ku.edu.kw

Received November 01, 2011; Accepted January 07, 2012; Published January 09, 2012

Citation: Al-Mutairi N (2012) Assessment of Traffic Noise Pollution Impact of Residential/Commercial Development. J Civil Environment Engg 2:105 doi:10.4172/2165-784X.1000105

Copyright: (c) 2012 Al-Mutairi N, et al. This is an open-access article distributed under the terms of the Creative Commons Attribution License, which permits unrestricted use, distribution, and reproduction in any medium, provided the original author and source are credited. 
Citation: Al-Mutairi N (2012) Assessment of Traffic Noise Pollution Impact of Residential/Commercial Development. J Civil Environment Engg 2:105. doi:10.4172/2165-784X.1000105

Page 2 of 3

\begin{tabular}{|c|c|c|c|c|c|c|c|c|}
\hline \multirow{2}{*}{$\begin{array}{l}\text { Roadway } \\
\text { Location }\end{array}$} & \multicolumn{4}{|c|}{ Morning Peak (veh/hr/dir) } & \multicolumn{4}{|c|}{ Afternoon Peak (veh/hr/dir) } \\
\hline & Small & Medium & Heavy & Total & Small & Medium & Heavy & Total \\
\hline No. 1 & $\begin{array}{l}1108 \\
1682 \\
1259\end{array}$ & $\begin{array}{l}904 \\
970 \\
1086\end{array}$ & $\begin{array}{l}38 \\
16 \\
33\end{array}$ & $\begin{array}{l}2050 \\
2668 \\
2378\end{array}$ & $\begin{array}{l}2089 \\
2278 \\
1881\end{array}$ & $\begin{array}{l}1660 \\
1905 \\
2018\end{array}$ & $\begin{array}{l}79 \\
72 \\
81\end{array}$ & $\begin{array}{l}3828 \\
4255 \\
3980\end{array}$ \\
\hline No. 2 & $\begin{array}{l}436 \\
382 \\
409\end{array}$ & $\begin{array}{l}300 \\
266 \\
271\end{array}$ & $\begin{array}{l}14 \\
21 \\
12\end{array}$ & $\begin{array}{l}750 \\
669 \\
692\end{array}$ & $\begin{array}{l}269 \\
261 \\
239\end{array}$ & $\begin{array}{l}216 \\
164 \\
198\end{array}$ & $\begin{array}{l}12 \\
23 \\
12\end{array}$ & $\begin{array}{l}497 \\
448 \\
449\end{array}$ \\
\hline No. 3 & $\begin{array}{l}373 \\
330 \\
405\end{array}$ & $\begin{array}{l}235 \\
285 \\
262\end{array}$ & $\begin{array}{l}11 \\
9 \\
8\end{array}$ & $\begin{array}{l}619 \\
624 \\
675\end{array}$ & $\begin{array}{l}223 \\
289 \\
405\end{array}$ & $\begin{array}{l}304 \\
285 \\
262\end{array}$ & $\begin{array}{l}13 \\
11 \\
12\end{array}$ & $\begin{array}{l}540 \\
585 \\
679\end{array}$ \\
\hline No. 4 & $\begin{array}{l}372 \\
403 \\
399\end{array}$ & $\begin{array}{l}266 \\
204 \\
275\end{array}$ & $\begin{array}{l}62 \\
55 \\
64\end{array}$ & $\begin{array}{l}700 \\
662 \\
738\end{array}$ & $\begin{array}{l}223 \\
281 \\
275\end{array}$ & $\begin{array}{l}209 \\
272 \\
240\end{array}$ & $\begin{array}{l}58 \\
44 \\
46\end{array}$ & $\begin{array}{l}550 \\
697 \\
561\end{array}$ \\
\hline No. 5 & $\begin{array}{l}956 \\
1035 \\
1026\end{array}$ & $\begin{array}{l}842 \\
647 \\
872\end{array}$ & $\begin{array}{l}83 \\
54 \\
86\end{array}$ & $\begin{array}{l}1881 \\
1736 \\
1984\end{array}$ & $\begin{array}{l}1481 \\
2178 \\
2002\end{array}$ & $\begin{array}{l}1245 \\
1287 \\
939\end{array}$ & $\begin{array}{l}88 \\
54 \\
66\end{array}$ & $\begin{array}{l}2814 \\
3519 \\
3007\end{array}$ \\
\hline No. 6 & $\begin{array}{l}312 \\
242 \\
322\end{array}$ & $\begin{array}{l}138 \\
119 \\
154\end{array}$ & $\begin{array}{l}7 \\
5 \\
4\end{array}$ & $\begin{array}{l}457 \\
366 \\
480\end{array}$ & \multicolumn{4}{|c|}{ Dust storm/traffic detour } \\
\hline No. 7 & $\begin{array}{l}168 \\
131 \\
201\end{array}$ & $\begin{array}{l}96 \\
134 \\
67\end{array}$ & $\begin{array}{l}2 \\
3 \\
1\end{array}$ & $\begin{array}{l}266 \\
268 \\
269\end{array}$ & $\begin{array}{l}125 \\
84 \\
74\end{array}$ & \begin{tabular}{|l}
104 \\
141 \\
58
\end{tabular} & $\begin{array}{l}3 \\
1 \\
3\end{array}$ & $\begin{array}{l}232 \\
226 \\
135\end{array}$ \\
\hline No. 8 & $\begin{array}{l}402 \\
392 \\
472\end{array}$ & $\begin{array}{l}270 \\
261 \\
349\end{array}$ & $\begin{array}{l}3 \\
1 \\
4\end{array}$ & $\begin{array}{l}675 \\
654 \\
825\end{array}$ & $\begin{array}{l}268 \\
143 \\
278\end{array}$ & $\begin{array}{l}265 \\
209 \\
258\end{array}$ & $\begin{array}{l}2 \\
3 \\
5\end{array}$ & $\begin{array}{l}535 \\
355 \\
541\end{array}$ \\
\hline
\end{tabular}

Table 1: Traffic Volume by Mix, Time and Roadway Location.

\begin{tabular}{|c|c|c|c|c|}
\hline \multirow{2}{*}{\begin{tabular}{|l|} 
Roadway \\
Location
\end{tabular}} & \multicolumn{2}{|c|}{ Morning Peak Hour } & \multicolumn{2}{|c|}{ Afternoon Peak Hour } \\
\hline & Small & Medium & Medium & Heavy \\
\hline No. 1 & \begin{tabular}{|l|}
86.4 \\
83.7 \\
86.4
\end{tabular} & $\begin{array}{l}2.4 \\
4.1 \\
2.4\end{array}$ & $\begin{array}{l}86.9 \\
86.1 \\
85.3\end{array}$ & $\begin{array}{l}3.4 \\
3.7 \\
5.1\end{array}$ \\
\hline No. 2 & \begin{tabular}{|l|}
83.1 \\
81.4 \\
81.5
\end{tabular} & $\begin{array}{l}5.3 \\
5.5 \\
4.1\end{array}$ & $\begin{array}{l}83.4 \\
84.5 \\
85.4\end{array}$ & $\begin{array}{l}6.2 \\
4.2 \\
4.3\end{array}$ \\
\hline No. 3 & \begin{tabular}{|l|}
83.6 \\
81.4 \\
81.3
\end{tabular} & $\begin{array}{l}4.3 \\
4.9 \\
2.5\end{array}$ & $\begin{array}{l}83.4 \\
84.5 \\
84.9\end{array}$ & $\begin{array}{l}6.2 \\
4.2 \\
4.3\end{array}$ \\
\hline No. 4 & \begin{tabular}{|l|}
84.9 \\
83.6 \\
84.6
\end{tabular} & $\begin{array}{l}6.3 \\
6.4 \\
4.1\end{array}$ & $\begin{array}{l}85.2 \\
87.1 \\
86.4\end{array}$ & $\begin{array}{l}6.3 \\
4.1 \\
4.6\end{array}$ \\
\hline No. 5 & \begin{tabular}{|l|}
86.8 \\
86.9 \\
86.4
\end{tabular} & $\begin{array}{l}4.3 \\
4.3 \\
5.4\end{array}$ & $\begin{array}{l}86.1 \\
87.1 \\
88.0\end{array}$ & $\begin{array}{l}4.8 \\
4.9 \\
3.9\end{array}$ \\
\hline No. 6 & $\begin{array}{l}77.4 \\
74.8 \\
77.7\end{array}$ & $\begin{array}{l}3.7 \\
6.1 \\
4.2\end{array}$ & \multicolumn{2}{|c|}{ Detour/Dust storm } \\
\hline No. 7 & $\begin{array}{l}71.6 \\
72.3 \\
73.2\end{array}$ & $\begin{array}{l}4.9 \\
4.8 \\
5.6\end{array}$ & $\begin{array}{l}76.5 \\
74.6 \\
74.7\end{array}$ & \begin{tabular}{|l|}
5.1 \\
3.8 \\
5.0
\end{tabular} \\
\hline No. 8 & $\begin{array}{l}78.6 \\
80.3 \\
79.2\end{array}$ & $\begin{array}{l}4.4 \\
5.3 \\
5.8\end{array}$ & $\begin{array}{l}81.6 \\
83.0 \\
81.1\end{array}$ & $\begin{array}{l}5.2 \\
5.7 \\
5.7\end{array}$ \\
\hline
\end{tabular}

Table 2: Traffic-Generated Noise levels by Time and Monitoring Location.

in the future will present a major problem to the community, both at work and at home.

\section{Correlation analysis}

A person correlation analysis was performed on the data to determine the degree of association between traffic-generated noise and causal variables. The resulting correlation coefficients conformed to expectations. The equivalent noise level, $\mathrm{L}_{e q}$ was positively and significantly (at the 95\% significance level) correlated with the volume of small vehicles $\left(\gamma_{x y}=0.562\right)$, medium-size vehicles $\left(\gamma_{x y}=0.555\right)$, heavy vehicles $\left(\gamma_{x y}=0.702\right)$, and obviously, with the total volume of traffic $\left(\gamma_{\mathrm{xy}}=0.575\right)$. The $\mathrm{L}_{\mathrm{eq}}$ was also positively and significantly associated with temperature $\left(\gamma_{x y}=0.256\right)$. Wind velocity and humidity did not demonstrate a significant correlation with the $\mathrm{L}_{\mathrm{eq}}$.

The trend relationship between the $\mathrm{L}_{\mathrm{eq}}$ and the volume of heavy vehicles as well as with temperature are presented in Figure 1 and 2. The data show that as the volume of traffic increased from less than 10 trucks/buses per hour, to more than 50 trucks/buses per hour Figure 1, the equivalent noise level increased from $77.6(\mathrm{dBA})$ to $85.5(\mathrm{dBA})$ - an increase of nearly 8 ( $\mathrm{dBA})$. The effect of temperature on noise level was obviously less pronounced as the data in Figure 2 indicate.

\section{Conclusion}

Heavy and continuous reliance on auto as the favored mode of 


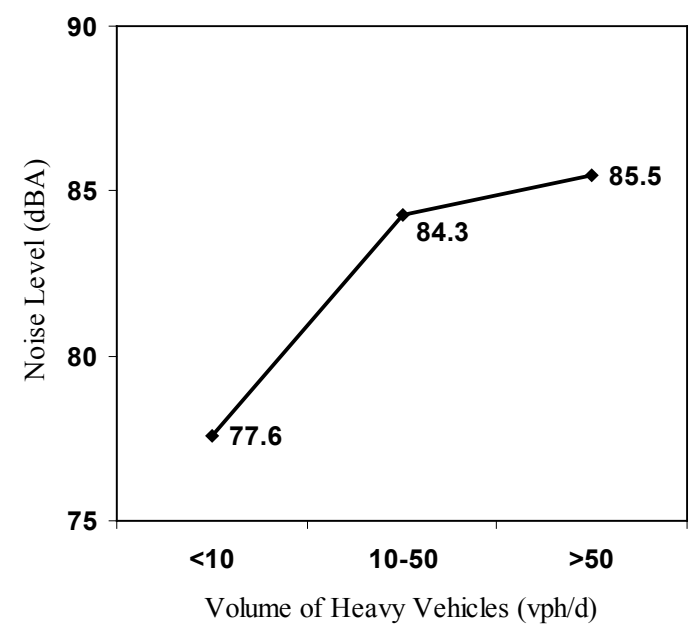

Figure 1: Volume of heavy vehicles and noise pollution level.

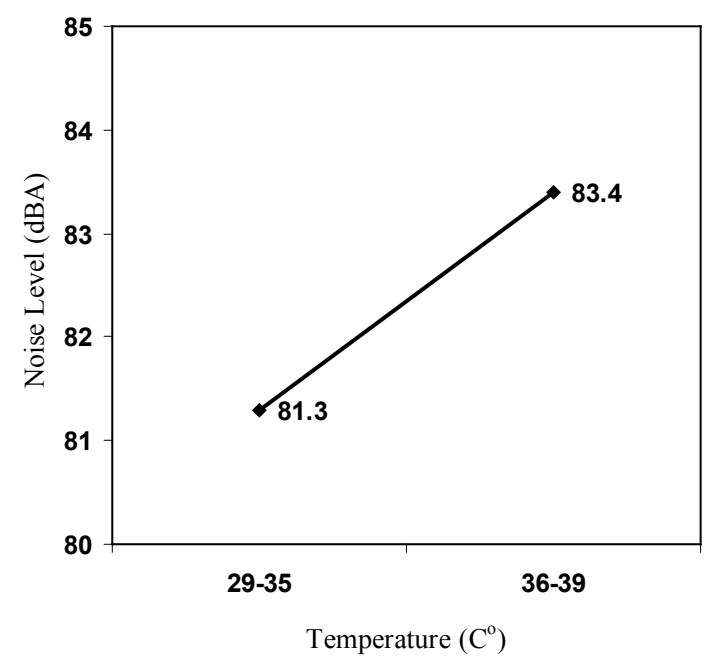

Figure 2: Temperature and noise pollution level. urban travel has resulted in daily congestion, noisy urban environment and has deteriorated the quality of urban life in Kuwait. The findings of the study have shown that traffic volumes on the roadways of Ahmadi are heavy and include a significant percentage of large trucks which transport materials for the booming construction industry in Kuwait. Consequently, the level of noise pollution from traffic even at the present time, exceed the outdoor standard limit by a significant margin. Additional growth in normal traffic plus that resulting from the redevelopment project will certainly create a disturbing noise environment in Ahmadi.

Traffic-generated noise at roadway locations number 1, 3, 4 and 5 is excessively high. It is recommended that no residential, hospital, school developments should take place on vacant lands adjacent to these roadways. Instead, a green band of trees/plants should be established on both sides of these roadways. This, would, at least psychologically, reduce the annoying impact of high noise level on the commercial land uses alongside these roads.

\section{References}

1. Belojevic G, Jakovljevic B (1997) Subjective Reactions to Traffic Noise with Regard to Some personality Traits. Environmental International 23: 221-226.

2. Koushki PA, Al-Saleh O, Ali S (1999) Traffic Noise in Kuwait: Profiles and Modeling Residents' Perceptions. J Urban Plann Dev 125: 101-109.

3. Ko NW (1978) Traffic Noise in a High-Rise City. Applied Acoustics 11: 225 239 .

4. Koushki PA, Kartam N, Al-Mutairi N (2003) Urban Development and Construction Noise: A Study in Metropolitan Kuwait. Kuwait J Sci Eng 30: 119138.

5. Koushki PA, Ali S, Mohammad B (2000) Trip Chaining Comparisons and Ligistic Models for Complex Trip Chains in Kuwait. Kuwait J Sci Eng 27: 261-278. 